\title{
ANTIDIABETIC AND ANTIHYPERLIPIDEMIC ACTIVITIES OF A NOVEL POLYHERBAL FORMULATION IN STREPTOZOTOCIN-NICOTINAMIDE-INDUCED DIABETIC WISTAR RATS
}

\author{
KISHOR KUMAR V ${ }^{1 *}$, LALITHA K G \\ ${ }^{1}$ Department of Pharmacognosy, J K K Nattraja College of Pharmacy, B. Kumarapalayam, Namakkal District, Tamil Nadu, India. \\ ${ }^{2}$ Department of Pharmaceutical Chemistry, Ultra College of Pharmacy, Madurai, Tamil Nadu, India. \\ Email: kishorkumar.v@jkkn.ac.in
}

Received: 12 February 2021, Revised and Accepted: 25 March 2021

ABSTRACT

Objective: The objective of the study was to investigate the antidiabetic and antihyperlipidemic activities of polyherbal formulation (PHF) containing seven plants, namely, Cassia auriculata, Cassia fistula, Syzygium cumini, Cyperus rotundus, Saussurea lappa, Terminalia arjuna, and Salacia reticulate in streptozotocin (STZ)-nicotinamide (NC)-induced diabetic rats by administering oral doses (200 and $400 \mathrm{mg} / \mathrm{kg}$ body weight).

Materials and Methods: Animals were divided into diabetic and non-diabetic groups. Rats were fed with normal laboratory diet and induced with a single intraperitoneal injection of $60 \mathrm{mg} / \mathrm{kg}$ of STZ, and thereafter, $120 \mathrm{mg} / \mathrm{kg} \mathrm{NC}$ was injected after $15 \mathrm{~min}$. Diabetic rats were treated with formulation (200 and 400 $\mathrm{mg} / \mathrm{kg}$ ) and glibenclamide $5 \mathrm{mg} / \mathrm{kg}$. Blood glucose levels were measured using blood glucose test strips with ACCU CHEK glucometer. Glycosylated hemoglobin $\left(\mathrm{HbA}_{1} \mathrm{C}\right)$, total haemoglobin $(\mathrm{Hb})$, lipid profiles, lipoproteins, and hepatic marker enzymes activity were determined in normal and STZ-NC-induced diabetic rats after oral administration of the PHF for 28 days. Histopathological changes in normal and diabetic rat pancreas organs were also observed after PHF treatment. The statistical analysis of results was carried out using one-way analysis (ANOVA) followed by Dunnett's post hoc multiple comparison tests.

Results: Treatment of diabetic rats with PHF (200 and $400 \mathrm{mg} / \mathrm{kg}$ ) and glibenclamide (5 mg/kg) indicates significant decreased blood glucose level and significant improvement in body weight. PHF-treated rats showed significant $(\mathrm{p}<0.01)$ decrease in the level of glycosylated Hb, total cholesterol, triglycerides, low-density lipoprotein, very low-density lipoprotein, aspartate amino transaminase, alanine amino transaminase, and alkaline phosphatase while a significant increment in the level of $\mathrm{Hb}$ and high-density lipoprotein cholesterol was observed. Furthermore, the PHF-treated rats have a favorable effect on the histopathological changes of the pancreas in STZ-NC-induced diabetes.

Conclusion: These findings suggested the antidiabetic and antihyperlipidemic properties of the PHF and thus help in preventing future complications of diabetes.

Keywords: Glibenclamide, Polyherbal formulation (PHF), Antidiabetic, Antihyperlipidemic, Type 2 diabetes.

(C) 2021 The Authors. Published by Innovare Academic Sciences Pvt Ltd. This is an open access article under the CC BY license (http://creativecommons.org/ licenses/by/4.0/) DOI: http://dx.doi.org/10.22159/ajpcr.2021v14i4.41523. Journal homepage: https://innovareacademics.in/journals/index.php/ajpcr

\section{INTRODUCTION}

In recent years, there has been renewed interest in the treatment against different diseases using herbal drugs, as they are generally non-toxic and the World Health Organization has recommended its effectiveness rather than the precarious modern drugs. Plant derivatives with hypoglycemic properties have been used in folk medicine and traditional healing systems around the world from ancient time [1]. Herbs and phytochemicals play a major role in the discovery of new therapeutic agents and have received attention as sources of antioxidants, hypoglycemic, and antihyperlipidemic agents. There are numerous traditional plants mentioned in Siddha and Ayurvedic system of medicine which are used as antidiabetic agents. Sharangdhar Samhita, an Ayurvedic literature from 1300 AD, has stressed the importance of polyherbalism [2].

Polyherbal formulations (PHFs) enhance the therapeutic action and reduce the concentrations of single herbs, thereby reducing the adverse events. Compared to the single herb, the PHF has better and multitargeted therapeutic potential. In the Ayurvedic system of medicine, several plants have been advocated for their hypoglycemic effects and are still in practice. Taking the lead from ancient literature seven plants, Cassia auriculata, Cassia fistula, Syzygium cumini, Cyperus rotundus, Saussurea lappa, Terminalia arjuna, and Salacia reticulate were selected out of various screened plants carried out for this purpose. In a traditional system, the plants of Cassia species are being used for asthma, antidiabetic, urinary disorders, nocturnal emission, antibilious, amebiasis antipyretic properties, etc., S. cumini called as "Naaval" is widely used a seed for hyperglycemia and polyuria. These plant parts having many constituents are used as lipid peroxidation in liver, anti-inflammatory, anti-arthritic, antipyretic, and analgesic activities [3]. The extracts of $C$. rotundus have been proved for its neuroprotective [4] and anti-inflammatory, anti-arthritic, analgesic, and anticonvulsant activity [5]. Another species of S. lappa have been extensively studied for its ameliorative effects [6] and antiviral efficacy [7]. Terminalia species are being proved for antidiabetic [8,9]. Furthermore, $S$. reticulate has been also proved for its antidiabetic [10]. The formulation is IPR protected and is already formulated. This study is to evaluate the antihyperglycemic and antihyperlipidemic activities of the PHF.

\section{MATERIALS AND METHODS}

Drugs and chemicals

Streptozotocin (STZ) (HiMedia, Mumbai), nicotinamide (NC) (HiMedia, Mumbai), and glibenclamide (Cipla, Mumbai) were used. All other chemicals and reagents were of analytical grade and enzymatic kits used in this study were obtained commercially.

\section{Composition of PHF}

The PHF was formulated into the Kudineer Chooranam as per the patent information of the effective doses by the SKM Siddha and Ayurveda Company India Ltd., Erode, Tamil Nadu, India. Each Kudineer Chooranam contains powders of C. auriculata (14.28\%), C. fistula 
(14.28\%), S. cumini (14.28\%), C. rotundus (14.28\%), S. lappa (14.28\%), T. arjuna (14.28\%), and S. reticulate (14.28\%) [11].

\section{Experimental animals}

Wistar albino rats of both sexes weighing (150-200 g) were used for the study [12]. All animals were maintained under standard laboratory conditions (temperature $\left[22 \pm 2^{\circ} \mathrm{C}\right]$ and humidity $\left[45 \pm 5^{\circ} \mathrm{C}\right]$ ) with a $12 \mathrm{~h}$ day: $12 \mathrm{~h}$ night cycle. The animals were fed with normal laboratory diet and allowed to drink water ad libitum. All the experimental protocols were approved by the Institutional Animal Ethics Committee and all the animal experiments were conducted according to the principles and guidelines of Committee for the Purpose of Control and Supervision of Experimentation on Animals, India.

\section{Acute oral toxicity study}

Acute oral toxicity study was performed as per organization for economic cooperation and development (OECD) guidelines 425 [13].

\section{Experimental induction of diabetes}

The animal model of type 2 diabetes mellitus (non-insulin-dependent diabetes mellitus [NIDDM]) was induced by single intraperitoneal injection of $60 \mathrm{mg} / \mathrm{kg}$ of STZ, and thereafter, $120 \mathrm{mg} / \mathrm{kg} \mathrm{NC}$ was injected after $15 \mathrm{~min}$. Hyperglycemia was confirmed by the elevated blood glucose levels determined at $72 \mathrm{~h}$ and then on day 7 of the injection. Only rats confirmed with permanent NIDDM were used in the antidiabetic study $[14,15]$. The diabetic rats were randomly divided into five groups each consisting of six rats and the study was continued up to 28 days.

\section{Experimental design}

Group I: Normal control rat group was fed basal diet throughout the experiment

Group II: STZ-NC-induced diabetic rats were treated with water

Group III: Diabetic rats treated with an oral dose of PHF $200 \mathrm{mg} / \mathrm{kg}$ b.w Group IV: Diabetic rats treated with an oral dose of PHF $400 \mathrm{mg} / \mathrm{kg} \mathrm{b.w}$ Group V: Diabetic rats treated with an oral dose of glibenclamide $5 \mathrm{mg} / \mathrm{kg}$ b.w.

PHF and glibenclamide were suspended in $2 \%$ gum acacia separately. Each dose was orally administered through oral gavage according to the body weight, daily for 28 days. Body weights and blood glucose levels were measured using blood glucose test strips with ACCU CHEK glucometer at weekly on overnight fasted animals. At the end of the experimental period, the animals were fasted an overnight and blood was collected for various biochemical estimations. The animals were sacrificed by cervical decapitation. Organs pancreas was dissected out, immediately rinsed in ice-cold saline, and stored for further biochemical estimations [16,17].

\section{Evaluation of biochemical parameters}

Serum was analyzed for hemoglobin $(\mathrm{Hb})$, glycosylated $\mathrm{Hb}\left(\mathrm{HbA}_{1} \mathrm{C}\right)$, total cholesterol (TC), triglycerides (TGs), high-density lipoprotein (HDL), aspartate amino transaminase (AST) or serum glutamate pyruvate transaminase (SGPT), alanine amino transaminase (ALT) or serum glutamate oxaloacetate transaminase (SGOT), and alkaline phosphatase (ALP) which were analyzed. Very low-density lipoprotein (VLDL) levels and low-density lipoprotein (LDL) were determined by following formula VLDL=TG/5; LDL=TC $-(\mathrm{HDL}+\mathrm{VLDL})$ [18-20]

\section{Histopathology}

The dissected pancreas was collected in $10 \%$ formalin solution and immediately processed by the paraffin technique. Sections of $5 \mu$ thickness were cut and stained by hematoxylin and eosin for histological examination [21].

\section{Statistical analysis}

All data were expressed as mean \pm standard error mean. Results were analyzed by one-way analysis of variance (ANOVA), and significant differences were determined by Dunnett's post hoc test using GraphPad Instat version 3.06 computer software.

\section{RESULTS}

\section{Effect of PHF on oral toxicity study}

In acute oral toxicity studies, a single dose of $2000 \mathrm{mg} / \mathrm{kg}$ PHF did not indicate modification of behavior (Table 1). No mortality and signs of toxicity were recorded during $24 \mathrm{~h}$ and up to 14 days observation (Table 2). The oral $\mathrm{LD}_{50}$ value of PHF must be $>2000 \mathrm{mg} / \mathrm{kg}$. Two hundred and $400 \mathrm{mg} / \mathrm{kg}$ of the PHF were selected for animal studies.

\section{Effect of PHF on body weight}

STZ-NC produced significant loss in body weight as compared to normal animals during the study. Diabetic control continued to lose weight till the end of the study while PHF (both doses) and glibenclamide showed significant improvement $(\mathrm{p}<0.01, \mathrm{p}<0.05)$ in body weight by $16.44 \%$, $20.06 \%$, and $21.16 \%$, respectively, compared to diabetic control rat group (Table 3 and Fig. 1)

\section{Effect of PHF on blood glucose level}

The antihyperglycemic effect of repeated oral administration of PHF (both doses) on fasting blood glucose levels in STZ-NC diabetic control rat group are presented in Table 4 . There was a significant increase in blood glucose level in diabetic control rat group when compared with normal controls due to injection of STZ-NC. The administration of PHF (both doses) and glibenclamide to STZ-NC treated diabetic control rat group caused significantly $(\mathrm{p}<0.01, \mathrm{p}<0.05)$ decline the blood glucose level when compared to normal control rats, which was related to dose and duration of treatment. At the end of experiment (the $28^{\text {th }}$ day) blood glucose level was $67.46 \%, 68.58 \%$ at the doses of 200 and $400 \mathrm{mg} / \mathrm{kg}$ of PHF respectively. The PHF at a dose $400 \mathrm{mg} / \mathrm{kg}$ showed higher $(\mathrm{p}<0.01)$ efficacy than $100 \mathrm{mg} / \mathrm{kg}$ dose in diabetic control rat group.

\section{Effect of PHF on $\mathrm{HbA}_{1} \mathrm{C}$ and $\mathrm{Hb}$ levels}

STZ-NC-induced diabetic rats showed a significantly $(\mathrm{p}<0.01)$ increase in the level of $\mathrm{HbA}_{1} \mathrm{C}$ and reduction of $\mathrm{Hb}$ level when compared with normal control rat group. Treatment with PHF (both doses) and glibenclamide treated diabetic rat groups caused significantly $(\mathrm{p}<0.01)$ reduction in $\mathrm{HbA}_{1} \mathrm{C}$ level, at the same time, increased in $\mathrm{Hb}$ level when compared with diabetic control rat group. The standard drug glibenclamide showed a marked reduction of the $\mathrm{HbA}_{1} \mathrm{C}$ level and elevation of $\mathrm{Hb}$ level which was similar to the PHF treated with $400 \mathrm{mg} / \mathrm{kg}$ (Table 5 and Fig. 2).

\section{Effect of PHF on lipid profile}

The result of the serum lipid profile (triglycerides [TG], total cholesterol [TC], low-density lipoprotein cholesterol [LDLC], and high-density lipoprotein cholesterol [HDLC]) revealed that there was elevation in the levels of serum TG, TC, and LDLC compared to the normal control rat group (Table 6). However, the levels of serum TG, TC, and

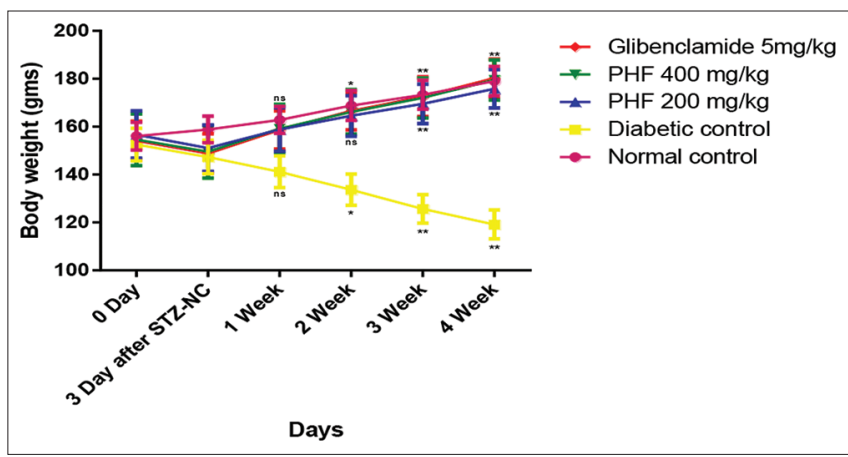

Figure 1: Effect of treatment with polyherbal formulation for 28 days on body weight of control and experimental groups of rats. The values are expressed as mean \pm SEM for groups of six animals each. Values are statistical significant at ${ }^{*} \mathbf{p}<0.05,{ }^{* *} \mathbf{p}<0.01$, ns - not significant, when compared to the corresponding values of the normal control. ${ }^{*} \mathbf{p}<0.05,{ }^{* *} \mathbf{p}<0.01$, ns - not significant, when compared to the corresponding values of the diabetic control 


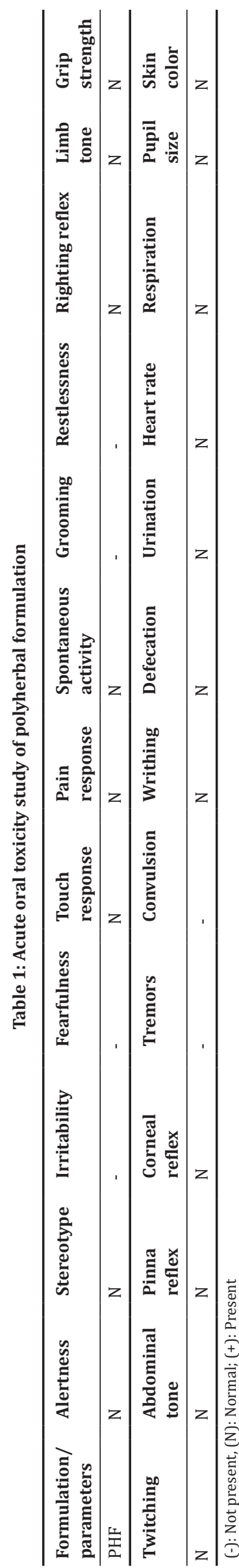

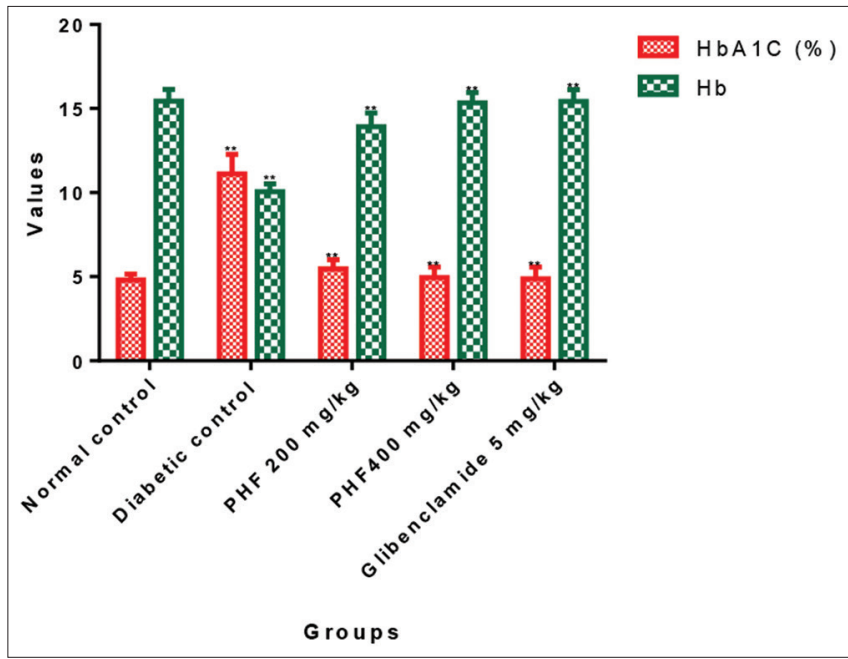

Figure 2: Effect of treatment with polyherbal formulation for 28 days on $\mathrm{HbA}_{1} \mathrm{C}$ and total $\mathrm{Hb}$ of control and experimental groups of rats. The values are expressed as mean \pm SEM for groups of six animals each. Values are statistical significant at ${ }^{* *} \mathbf{p}<0.01$

when compared to the corresponding values of the normal control. ${ }^{* *} \mathbf{p}<0.01$ when compared to the corresponding values of the diabetic control

LDLC were significantly $(\mathrm{p}<0.01)$ reduced in groups treated with PHF (both doses) and glibenclamide treated diabetic control rat group. Furthermore, plasma HDLC was reduced in diabetic control rat group when compared with the normal control rat group. However, the level of HDLC was significantly $(\mathrm{p}<0.05)$ elevated in PHF (both doses) and glibenclamide treated diabetic control rat groups when compared with diabetic control rat group.

\section{Effect of PHF on serum hepatic marker enzymes profile}

The result of the serum hepatic marker enzymes such as AST, ALT, and ALP levels was significantly $(\mathrm{p}<0.01)$ increased in the diabetic control rat group compared with the normal control rat group. In treatment with PHF (both doses) and glibenclamide treated diabetic control rat groups, there was a significant $(\mathrm{p}<0.01)$ reduction of AST, ALT, and ALP, respectively, as compared with the diabetic control rat group (Table 7). The maximum lowering of hepatic enzymes such as AST, ALT, and ALP in STZ-NC-induced diabetic rats was appeared in PHF $400 \mathrm{mg} / \mathrm{kg}$ dose than $200 \mathrm{mg} / \mathrm{kg}$.

\section{Effect of PHF on histopathological study}

Histopathology of the pancreas in normal control rat group showed normal pancreatic parenchyma cells and islet cell (Fig. 3a). STZ-NCinduced diabetic rats result in degenerative changed in the islets of Langerhans of the pancreas, such as moderate hyperplasia of islet cells, severe congestion in the pancreatic parenchyma, and mild infiltration of inflammatory cells (Fig. 3b). Treatment with PHF and glibenclamide restored the activity of the islets of Langerhans (Fig. 3c-e).

\section{DISCUSSION}

The present investigation discusses the antidiabetic and antihyperlipidemic potential of the PHF in STZ-NC-induced diabetic rats. The use of STZ to induce DM in rat models is widely accepted and STZ-induced diabetes is reported to resemble human DM [22] which is characterized by glycosuria, hyperglycemia, polyphagia, polydipsia, and body weight loss when compared with normal rodents [18]. In our study, we used STZ-NC for induction of type 2 DM. STZ causes selective cytotoxicity effect on pancreatic beta cells and thus it affects the endogenous insulin release and as a result increases blood glucose level [23]. Due to an antioxidant property of NC, it exerts protective effect on the cytotoxic action of STZ by scavenging free radicals and causes only minor damage to pancreatic $\beta$-cell mass producing type 2 DM [14]. 
Table 2: $\mathrm{LD}_{50}$ determination of polyherbal formulation

\begin{tabular}{|c|c|c|c|c|c|c|c|}
\hline Group & $\begin{array}{l}\text { Dose } \\
\text { (mg/kg) }\end{array}$ & $\begin{array}{l}\text { Dose } \\
\text { difference (a) }\end{array}$ & Dead & $\begin{array}{l}\text { Mean } \\
\text { mortality (b) }\end{array}$ & $(a \times b)$ & $\Sigma(\mathbf{a} \times \mathbf{b})$ & $\begin{array}{l}\text { LD50 }=\text { dose }(\max )-(\Sigma(\mathbf{a} \times \mathbf{b}) / \\
\text { No. of animals })\end{array}$ \\
\hline 1 & 175 & - & 00 & - & - & 0 & $2000 \mathrm{mg} / \mathrm{kg}$ \\
\hline 2 & 550 & 375 & 00 & - & - & & \\
\hline 3 & 2000 & 1450 & 00 & - & - & & \\
\hline
\end{tabular}

Table 3: Effect of treatment with polyherbal formulation for 28 days on body weight of control and experimental groups of rats

\begin{tabular}{|c|c|c|c|c|c|c|c|c|}
\hline \multirow[t]{3}{*}{ Group } & \multirow[t]{3}{*}{ Treatment } & \multirow{3}{*}{$\begin{array}{l}\text { Dose } \\
\text { (mg/kg) }\end{array}$} & \multicolumn{6}{|c|}{ Body weight (g) } \\
\hline & & & \multicolumn{6}{|c|}{ Treatment days } \\
\hline & & & 0 day & $\begin{array}{l}3 \text { days after } \\
\text { STZ }\end{array}$ & $1^{\text {st }}$ week & $2^{\text {nd }}$ week & $3^{\text {rd }}$ week & $4^{\text {th }}$ week \\
\hline I & $\begin{array}{l}\text { Normal } \\
\text { control }\end{array}$ & ----- & $156.00 \pm 5.82$ & $158.83 \pm 5.55$ & $162.83 \pm 5.63$ & $168.83 \pm 6.19$ & $173.33 \pm 6.05$ & $179.00 \pm 6.11$ \\
\hline II & $\begin{array}{l}\text { Diabetic } \\
\text { control }\end{array}$ & ------ & $152.50 \pm 6.78$ & $147.33 \pm 6.93$ & $141.16 \pm 6.59^{\mathrm{ns}}$ & $133.66 \pm 6.51^{*}$ & $125.66 \pm 5.99 * *$ & $119.16 \pm 6.05^{* *}$ \\
\hline III & PHF & 200 & $156.66 \pm 9.85$ & $151.00 \pm 9.74$ & $158.83 \pm 9.16^{\mathrm{ns}}$ & $164.50 \pm 8.43^{\text {ns }}$ & $169.50 \pm 8.18^{* *}$ & $175.83 \pm 8.04^{* *}$ \\
\hline IV & PHF & 400 & $154.50 \pm 10.83$ & $149.50 \pm 10.92$ & $159.16 \pm 10.11^{\mathrm{ns}}$ & $166.16 \pm 9.32^{*}$ & $172.00 \pm 8.34^{* *}$ & $179.50 \pm 8.38^{* *}$ \\
\hline $\mathrm{V}$ & Glibenclamide & 5 & $154.16 \pm 8.14$ & $148.83 \pm 8.22$ & $158.66 \pm 8.00^{\text {ns }}$ & $166.50 \pm 7.84 *$ & $172.50 \pm 8.28^{* *}$ & $180.33 \pm 7.91^{* *}$ \\
\hline
\end{tabular}

The values are expressed as mean \pm SEM for groups of six animals each. Values are statistical significant at *p $<0.05,{ }^{* *} \mathrm{p}<0.01$, ns - not significant, when compared to the corresponding values of the normal control. ${ }^{*} \mathrm{p}<0.05,{ }^{* *} \mathrm{p}<0.01$, ns - not significant, when compared to the corresponding values of the diabetic control

Table 4: Effect of treatment with polyherbal formulation for 28 days on fasting blood glucose level of control and experimental groups of rats

\begin{tabular}{|c|c|c|c|c|c|c|c|c|}
\hline \multirow[t]{3}{*}{ Group } & \multirow[t]{3}{*}{ Treatment } & \multirow{3}{*}{$\begin{array}{l}\text { Dose } \\
\text { (mg/kg) }\end{array}$} & \multicolumn{6}{|c|}{ Fasting blood glucose level (mg/dL) } \\
\hline & & & \multicolumn{6}{|c|}{ Treatment days } \\
\hline & & & 0 day & $\begin{array}{l}3 \text { days after } \\
\text { STZ }\end{array}$ & $1^{\text {st }}$ week & $2^{\text {nd }}$ week & $3^{\text {rd }}$ week & $4^{\text {th }}$ week \\
\hline I & $\begin{array}{l}\text { Normal } \\
\text { control }\end{array}$ & ---- & $88.83 \pm 7.38$ & $91.66 \pm 8.22$ & $88.66 \pm 8.13$ & $86.16 \pm 5.61$ & $87.50 \pm 6.91$ & $84.66 \pm 4.44$ \\
\hline II & $\begin{array}{l}\text { Diabetic } \\
\text { control }\end{array}$ & ----- & $91.66 \pm 5.77$ & $331.50 \pm 48.03$ & $338.33 \pm 40.86^{* *}$ & $346.83 \pm 44.72^{* *}$ & $357.33 \pm 36.06^{* *}$ & $360.16 \pm 28.62^{* *}$ \\
\hline III & PHF & 200 & $89.50 \pm 8.30$ & $326.83 \pm 50.70$ & $280.33 \pm 36.88^{\text {ns }}$ & $216.16 \pm 25.18^{*}$ & $127.33 \pm 16.01^{* *}$ & $106.33 \pm 10.81^{* *}$ \\
\hline IV & PHF & 400 & $86.83 \pm 7.02$ & $312.00 \pm 32.19$ & $258.66 \pm 34.50^{\mathrm{ns}}$ & $185.33 \pm 20.28^{* *}$ & $110.66 \pm 15.39 * *$ & $98.00 \pm 1246^{* *}$ \\
\hline V & Glibenclamide & 5 & $90.33 \pm 6.20$ & $334.33 \pm 29.48$ & $240.66 \pm 36.79^{\text {ns }}$ & $172.16 \pm 21.37^{* *}$ & $108.50 \pm \pm 14.83^{* *}$ & $97.16 \pm 13.08^{* *}$ \\
\hline
\end{tabular}

The values are expressed as mean \pm SEM for groups of six animals each. Values are statistical significant at $* * \mathrm{p}<0.01$ when compared to the corresponding values of the normal control. ${ }^{*} \mathrm{p}<0.05,{ }^{* *} \mathrm{p}<0.01, \mathrm{~ns}-$ not significant, when compared to the corresponding values of the diabetic control

Table 5: Effect of treatment with polyherbal formulation for 28 days on glycosylated hemoglobin and total hemoglobin of control and experimental groups of rats

\begin{tabular}{lllll}
\hline Group & Treatment & $\begin{array}{l}\text { Dose } \\
(\mathbf{m g} / \mathbf{k g})\end{array}$ & HbA $_{\mathbf{1}} \mathrm{C}(\%)$ & Hb (gm/dL) \\
\hline I & $\begin{array}{l}\text { Normal } \\
\text { control }\end{array}$ & ---- & $4.81 \pm 0.34$ & $15.45 \pm 0.70$ \\
& $\begin{array}{l}\text { Diabetic } \\
\text { II }\end{array}$ & ----- & $11.11 \pm 1.17^{* *}$ & $10.06 \pm 0.47^{* *}$ \\
& PHF & 200 & $5.47 \pm 0.54^{* *}$ & $13.93 \pm 0.81^{* *}$ \\
III & PHF & 400 & $4.95 \pm 0.63^{* *}$ & $15.34 \pm 0.62^{* *}$ \\
IV & Glibenclamide & 5 & $4.87 \pm 0.70^{* *}$ & $15.42 \pm 0.71^{* *}$ \\
V &
\end{tabular}

The values are expressed as mean \pm SEM for groups of six animals each. Values are statistical significant at ${ }^{* *} \mathrm{p}<0.01$ when compared to the corresponding values of the normal control. ${ }^{* *} \mathrm{p}<0.01$ when compared to the corresponding values of the diabetic control

Oral administration of PHF to the diabetic rats showed significant reduction of blood glucose levels in a dose-dependent manner and also at $400 \mathrm{mg} / \mathrm{kg}$ dose level of PHF exhibited the parallel effect to that of glibenclamide (Table 4). Glibenclamide is a standard antihyperglycemic drug that stimulates insulin secretion from $\beta$-cell of islets of Langerhans. From the results of the present study, it may be suggested that the mechanism of action of PHF may be similar to glibenclamide action [24].

In the present investigation, it was observed that the body weight of STZ-NC-induced diabetic control rats group gradually decreased when compared to the normal control rats group indicating the impaired glucose metabolism. Induction of diabetes by STZ leads to loss of body weight due to increased muscle wasting and loss of tissue proteins [25]. Treatment with PHF, gain in body weight was recognized in diabetic control rats group, and the results were comparable with that of the standard drug, glibenclamide (Fig. 1).

The $\mathrm{HbA}_{1} \mathrm{C}$ is an essential biochemical parameter in diabetes, which helps to establish the degree of protein glycation during diabetes [26]. In STZ-NC-induced diabetic rats, significantly decreased $\mathrm{Hb}$ and increased $\mathrm{HbA}_{1} \mathrm{C}$ levels were noticed than control rats. Treatment with PHF and glibenclamide showed downgrading of $\mathrm{HbA1C}$ and upgrading of $\mathrm{Hb}$ levels was observed. This result might be due to blood glucose lowering effect of PHF probably through reversal of insulin resistance or rising insulin secretion by regeneration of pancreatic $\beta$-cells [24] (Fig.2).

Hypercholesterolemia and hypertriglyceridemia are most essential factors of diabetic state involved in the progression of atherosclerosis 
Table 6: Effect of treatment with polyherbal formulation for 28 days on total cholesterol, triglycerides, HDL, LDL, and VLDL of control and experimental groups of rats

\begin{tabular}{|c|c|c|c|c|c|c|c|}
\hline Group & Treatment & $\begin{array}{l}\text { Dose } \\
\text { (mg/kg) }\end{array}$ & $\begin{array}{l}\text { Total cholesterol } \\
(\mathrm{mg} / \mathrm{dL})\end{array}$ & $\begin{array}{l}\text { Triglycerides } \\
\text { (mg/dL) }\end{array}$ & HDL (mg/dL) & LDL (mg/dL) & VLDL (mg/dL) \\
\hline I & $\begin{array}{l}\text { Normal } \\
\text { control }\end{array}$ & - & $128.83 \pm 7.09$ & $83.50 \pm 5.75$ & $55.00 \pm 5.50$ & $57.13 \pm 11.39$ & $16.70 \pm 1.15$ \\
\hline II & $\begin{array}{l}\text { Diabetic } \\
\text { control }\end{array}$ & ------ & $241.33 \pm 15.95^{* *}$ & $210.16 \pm 10.46^{* *}$ & $28.66 \pm 3.16^{* *}$ & $170.63 \pm 15.00^{* *}$ & $42.03 \pm 2.09^{* *}$ \\
\hline III & PHF & 200 & $149.00 \pm 12.55^{* *}$ & $101.50 \pm 8.66^{* *}$ & $48.83 \pm 7.39 *$ & $79.86 \pm 13.95^{* *}$ & $20.30 \pm 1.73^{* *}$ \\
\hline IV & PHF & 400 & $130.83 \pm 9.57^{* *}$ & $89.50 \pm 9.30^{* *}$ & $54.00 \pm 5.11^{*}$ & $76.83 \pm 9.80^{* *}$ & $17.90 \pm 1.86^{* *}$ \\
\hline
\end{tabular}

The values are expressed as mean \pm SEM for groups of six animals each. Values are statistical significant at $* *$ p $<0.01$ when compared to the corresponding values of the normal control. ${ }^{*} \mathrm{p}<0.05,{ }^{* *} \mathrm{p}<0.01$ when compared to the corresponding values of the diabetic control

Table 7: Effect of treatment with polyherbal formulation for 28 days on AST, ALT, and ALP of control and experimental groups of rats

\begin{tabular}{llllll}
\hline Group & Treatment & Dose $(\mathrm{mg} / \mathbf{k g})$ & AST $(I U / L)$ & ALT (IU/L) & ALP (IU/L) \\
\hline I & Normal control & ---- & $34.16 \pm 3.96$ & $47.50 \pm 9.26$ & $100.16 \pm 7.08$ \\
II & Diabetic control & ---- & $147.00 \pm 11.05^{* *}$ & $157.50 \pm 10.25^{* *}$ & $250.50 \pm 23.38^{* *}$ \\
III & PHF & 200 & $45.33 \pm 11.63^{* *}$ & $52.83 \pm 9.90^{* *}$ & $111.50 \pm 14.39^{* *}$ \\
IV & PHF & 400 & $39.33 \pm 12.09^{* *}$ & $49.50 \pm 10.85^{* *}$ & $105.83 \pm 10.92^{* *}$ \\
V & Glibenclamide & 5 & $37.83 \pm 11.54^{* *}$ & $48.66 \pm 10.38^{* *}$ & $102.33 \pm 8.01^{* *}$ \\
\hline
\end{tabular}

The values are expressed as mean \pm SEM for groups of six animals each. Values are statistical significant at ${ }^{* *} p<0.01$ when compared to the corresponding values of the normal control. ${ }^{* *} \mathrm{p}<0.01$ when compared to the corresponding values of the diabetic control

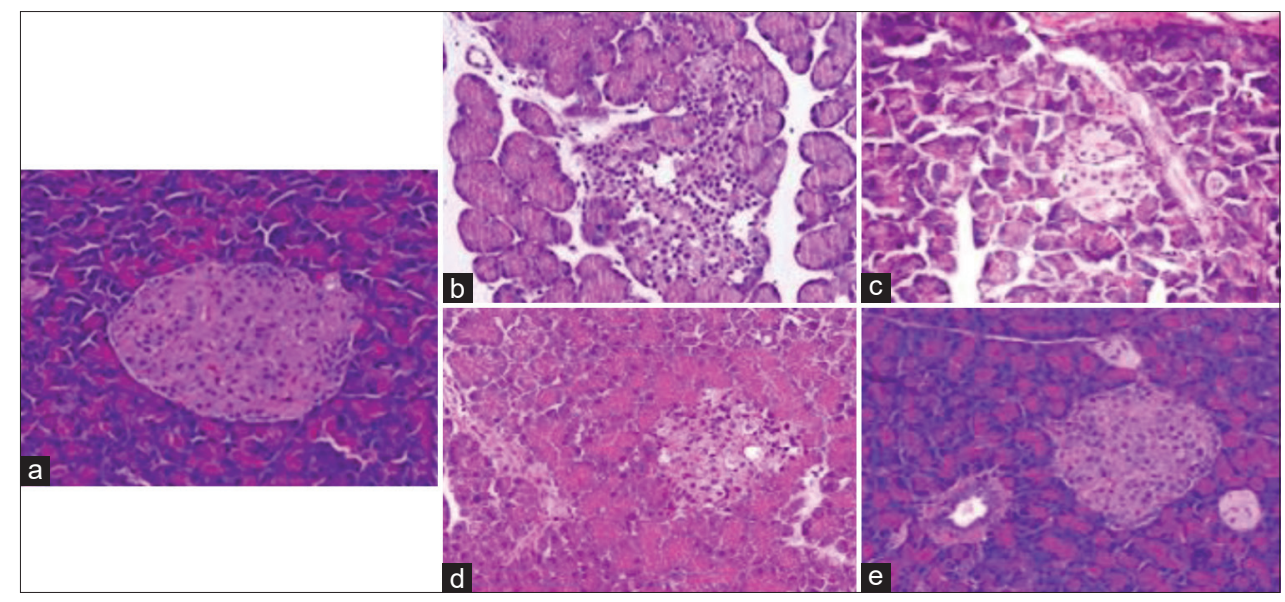

Figure 3: Effect of treatment with polyherbal formulation for 28 days on cellular damage in pancreas of control and experimental groups of rats. $a=$ Normal control (normal acini with islets of $\beta$-cells), $b=$ Diabetic control (atrophic acini and reduction of $\beta$-cell size; shows degreased islets), $c=$ Glibenclamide (markedly normal regenerated and preserved cells; with marked proliferated and regenerated $\beta$-cells), d=PHF $200 \mathrm{mg} / \mathrm{kg}$ (shows hyperplastic condition; with marked increased proliferation of (hyperplastic) $\beta$-cells), e=PHF $400 \mathrm{mg} / \mathrm{kg}$ (shows pancreas with acini and normal islets. $\beta$-cell regeneration and markedly normal regenerated and preserved cells; with marked proliferated and regenerated $\beta$-cells)

and coronary heart disease which are the secondary complications of diabetes [27]. Our results specify that treatment with PHF and glibenclamide administered to diabetic control rats group reduced TC, LDL cholesterol, VLDL cholesterol, and lowed serum levels of HDL cholesterol. Thus, PHF at the dose of $400 \mathrm{mg} / \mathrm{kg}$ could have a potential to reduce long-term cardiovascular complications in diabetic conditions.

In STZ-NC-induced diabetic rats, the liver was necrotized. An increase in the activities of AST, ALT, and ALP in plasma might be mostly due to the leakage of these enzymes from the liver cytosol into the blood stream which gives an indication of the hepatotoxic effect of STZ [28]. Hence, our study was also focused to know the protective activity of PHF against hepatic and renal damage caused by diabetes. Treatment of the diabetic control rat group with PHF and glibenclamide reduced the activity of these enzymes when compared to the diabetic control rat group and consequently alleviated liver damage caused by STZ-NC- induced diabetes rats. Significant reductions in the activities of these enzymes in PHF-treated diabetic rats indicated the hepatoprotective role in preventing diabetic complications.

Histopathology of the pancreas in normal control rat group showed normal pancreatic parenchyma cells and islet cell (Fig. 3a). STZ-NCinduced diabetic rats result in degenerative changed in the islets of Langerhans of the pancreas (Fig. 3b) due to moderate hyperplasia of islet cells with severe congestion in the pancreatic parenchyma and mild infiltration of inflammatory cells, nitric oxide production, and free radical generation, leading to a total lack or deprived insulin production and chronic hyperglycemia [29]. The islet is considerably reduced and shrunken, there is the destruction of some $\beta$-cells with central hyalinization with pyknotic nuclei and the number of cells is lower [30]. Treatment with PHF and glibenclamide restored the activity of the islets of Langerhans (Fig. 3c-e). 


\section{CONCLUSION}

The novel polyherbal preparation supplemented in the present study exhibited antidiabetic effect parallel effect to that of glibenclamide and reversal of deteriorated liver marker enzymes and lipid profile of type 2 diabetic rats. Clinical trials employing such novel herbal preparations would be of great interest and beneficial to disease management and human welfare at large.

\section{ACKNOWLEDGMENT}

The authors were grateful to management and principal, who took interest in looking into our research needs and thus providing us with the best available resources.

\section{AUTHORS' CONTRIBUTIONS}

All authors were contributed to the idea, design the study, draft the article, review the data, and edit the article.

\section{REFERENCES}

1. Yeh GY, Eisenberg DM, Kaptchuk TJ, Phillips RS. Systematic review of herbs and dietary supplements for glycemic control in diabetes. Diabetes Care 2003;26:1277-94.

2. Srivastava S, Lal VK, Pant KK. Polyherbal formulations based on Indian medicinal plants as antidiabetic phytotherapeutics. Phytopharmacology 2012;2:1-15

3. Khare CP. Indian Medicinal Plants: An Illustrated Dictionary. New Delhi: Springer Publication; 2004. p. 127-8, 637

4. Sutalangka C, Wattanathorn J. Neuroprotective and cognitiveenhancing effects of the combined extract of Cyperus rotundus and Zingiber officinale. BMC Complement Altern Med 217;17:135.

5. Birder S, Kangralkar VA, Mandavkar Y, Thakur M, Chougule N. Antiinflammatory, anti-arthritic, analgesic and anticonvulsant activity of Cyperus essential oils. Int J Pharm Pharm Sci 2010;2:128-30.

6. Abd Eldaim MA, Tousson E, El Sayed IT, Awd WM. Ameliorative effects of Saussurea lappa root aqueous extract against ethephon-induced reproductive toxicity in male rats. Environ Toxicol 2019;34:150-9.

7. Ansari S, Siddiqui MA, Malhotra S, Maaz M. Antiviral efficacy of qust (Saussurea lappa) and afsanteen (Artemisia absinthium) for chronic hepatitis B: A prospective single-arm pilot clinical trial. Pharmacogn Res 2018;10:282-90.

8. Ragavan B, Krishnakumari S. Antidiabetic effect of T. arjuna bark extract in alloxan induced diabetic rats. Indian J Clin Biochem 2006;21:123-8.

9. Biswas M, Kar B, Bhattacharya S, Kumar RB, Ghosh AK, Haldar PK. Antihyperglycemic activity and antioxidant role of Terminalia arjuna leaf in streptozotocin-induced diabetic rats. Pharm Biol 2011;49:335-40.

10. Yoshino K, Miyauchi Y, Kanetaka T, Takagi Y, Koga K. Anti-diabetic activity of a leaf extract prepared from Salacia reticulata in mice. Biosci Biotechnol Biochem 2009;73:1096-104.

11. Anonymous. The Siddha Formulary of India: Part 1. India, Ministry of Health and Family Welfare. New Delhi: Government of India, Ministry of Health and Family Welfare, Department of Health; 1992.2.

12. Selvamani P, Latha S, Elayaraja K, Babu PS, Gupta JK, Pal TK, et al. Antidiabetic activity of the ethanol extract of Capparis sepiaria $\mathrm{L}$ leaves. Indian J Pharm Sci 2008;70:378-80.

13. Organization for Economic Cooperation and Development. OECD
Guidelines for Testing of Chemicals. Section 4, Health Effects: Test No. 425: Acute Oral Toxicity: Up-and-Down Procedure. France: OECD Publishing; 2006. p. 1-27. Available from: htt://www.oecdbookshop. org/oecd/index.asp/langen. [Last accessed on 2006 Mar 23].

14. Masiello P, Broca C, Gross R, Roye M, Manteghetti M, HillaireBuys D, et al. Experimental NIDDM: Development of a new model in adult rats administered with streptozotocin and nicotinamide. Diabetes 1998;47:224-9.

15. Sam I, Punitha R, Shirwaikar A, Shirwaikar A. Antidiabetic activity of benzyl tetra isoquinoline alkaloid berberine in streptozotocin-nicotinamide induced Type 2 diabetic rats. Diabetol Croat 2005;34:117-28.

16. Annie S, Rajendran K, Sam I, Punitha R. Antidiabetic activity of alcoholic stem extract of Coscinium fenestratum in streptozotocinnicotinamide induced Type 2 diabetic rats. J Ethnopharmacol 2005;97:369-374.

17. Kumar EK, Janardhana GR. Antidiabetic activity of alcoholic stem extract of Nervilia plicata in streptozotocin-nicotinamide induced Type 2 diabetic rats. J Ethnopharmacol 2011;133:480-3.

18. Kumar S, Kumar V, Prakash O. Antidiabetic and antilipemic effects of Cassia siamea leaves extract in streptozotocin induced diabetic rats. Asian Pac J Trop Med 2010;3:871-3.

19. Babu V, Gangadevi T, Subramoniam A. Antidiabetic activity of ethanol extract of Cassia kleinii leaf in streptozotocin-induced diabetic rats and isolation of an active fraction and toxicity evaluation of the extract. Indian J Pharmacol 2003;35:290-6.

20. Reitman S, Frankel S. Colorimetric method for the determination of serum glutamate oxalo-acetate and glutamate pyruvate transaminase. Am J Clin Pathol 1957;28:56-63.

21. Selvan VT, Manikandan L, Kumar GP, Suresh R, Kakoti BB, Gomathi $\mathrm{P}$, et al. Antidiabetic and antioxidant effect of methanol extract of Artanema sesamoides in streptatozocin-induced diabetic rats. Int J Appl Res Nat Prod 2008;1:25-33.

22. Adisa RA, Choudhary MI, Olorunsogo OO. Hypoglycemic activity of Buchholzia coriacea (Capparaceae) seeds in streptozotocin-induced diabetic rats and mice. Exp Toxicol Pathol 2011;63:619-25.

23. Nastaran JS. Antihyperglycaemia and antilipidaemic effect of Zizipus vulgaris $\mathrm{L}$ on streptozotocin induced diabetic adult male Wister rats. Physiol Pharmacol 2011;47:219 -23.

24. Arunachalam K, Parimelazhagan T. Antidiabetic activity of Ficus amplissima Smith bark extract in streptozotocin induced diabetic rats. J Ethnopharmacol 2013;147:302-10.

25. Swanston-Flatt SK, Day C, Flatt PR, Gould BJ, Bailey CJ. Glycaemic effects of traditional European plant treatments for diabetes. Studies in normal and streptozotocin diabetic mice. Diabetes Res 1989;10:69-73.

26. Deguchi Y, Miyazaki K. Anti-hyperglycemic and anti-hyperlipidemic effects of guava leaf extract. Nutr Metab 2010;7:9.

27. Ananthan R, Latha M, Ramkumar KM, Pari L, Baskar C, Bai VN. Effect of Gymnema montanum leaves on serum and tissue lipids in alloxan diabetic rats. Exp Diabesity Res 2003;4:183-9.

28. Kasetti RB, Rajasekhar MD, Kondeti VK, Fatima SS, Kumar EG, Swapna S, et al. Antihyperglycemic and antihyperlipidemic activities of methanol: Water (4:1) fraction isolated from aqueous extract of Syzygium alternifolium seeds in streptozotocin induced diabetic rats. Food Chem Toxicol 2010;48:1078-84.

29. Lenzen S. The mechanism of alloxan and streptozotocin induced diabetes. Diabetologia 2008;51:216-26.

30. Shanmugasundaram ER, Gopinath KL, Shanmugasundaram KR, Rajendran VM. Possible regeneration of the islets of langerhans in streptozotocin-diabetic rats given Gymnema sylvestre leaf extracts. J Ethnopharmacol 1990;30:265-79. 